\title{
Articles
}

The Person and the Challenges

Volume 4 (2014) Number 2, p. 5-16

DOI: http://dx.doi.org/10.15633/pch.658

Mirosław Łanoszka

The Pontifical University of John Paul II in Krakow, Poland

\section{The Relationship between God and Israel as a Biblical Portrayal of the Bond between God and the Person in the Light of Deuteronomy 1:1-4:43}

\begin{abstract}
As the fifth book of the Pentateuch, Deuteronomy depicts a panoramic synthesis of the entire history of Israel. Consequently, its message is very important for Old Testament theology. Deuteronomy had its origin as a book of God's Law, communicated to the Israelites by Moses, giving them in a certain way the best guidance possible through the course of their history. The Book of Deuteronomy raises important issues in the life and faith of the Israelites just as they prepare to enter the land of promise. The most important of them is the relationship between God and Israel; that direct connection of Israel's obedience to the divine law that should be treated as 'rule of life' in the Promised Land. Moses' first address to Israel (Deut 1:1-4:43) allows us to capture generally the essential elements that influence both positively and negatively on forming the vital relationship with God: the only One who can provide for every person a happy life - lived to the full.
\end{abstract}

\section{Keywords}

God-Israel relationship, Deuteronomy, law, faithfulness, idolatry, dāb $\underline{b} a q$.

The Book of Deuteronomy has an important influence on determining the shape of the literary structure as well as the theology of the Old Testament 
writings ${ }^{1}$. Deuteronomy is the fifth book of the Old Testament, so it belongs to the Pentateuch (Gen, Ex, Lev, Num, Deut). Moreover it functions as an introduction to the theological work known as the Deuteronomistic History (Josh, Judg, 1 Sam, 2 Sam, 1 Kings, 2 Kings) $)^{2}$."The original Deuteronomy was a lawbook"3 containing the law which God communicated to Israel through Moses (Deut 12-26). This "book of the law" became the essential guide for Israelites through the course of their history. Deuteronomy provides the hermeneutical key for the correct understanding of the Old Testament law and its role in revealing the divine will. The understanding of law within the Book of Deuteronomy maybe summarized

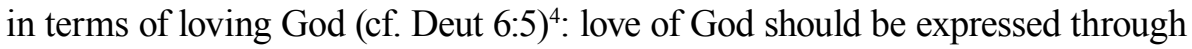
actions $^{5}$. This is the reason the message of Deuteronomy is still a matter of great importance to the life and faith of the truly religious communities of Jews and Christians today. This book protects every believer from all forms of legalism, indicating that forming an intimate relationship with the one and only God allows a person to live a happy life to the full (cf. Deut 30:19-20). The relationship between God and Israel was portrayed in the early chapters of Deuteronomy, just prior to Israel's crossing into the Promised Land. Since this intimate bond with God is most important for the life of every person, it is worth finding the essential elements forming this vital relationship in the message of these texts.

\section{The law given to Israel as a consequence of a relationship with God}

"These are the words that Moses spoke to all Israel beyond the Jordan - in the wilderness (...) Beyond the Jordan in the land of Moab, Moses undertook to expound this law as follows (...)" (Deut 1:1.5) .

1 B. S. Childs, Introduction to the Old Testament as Scripture, Philadelphia 2011, Fortress Press, p. 204.

2 "Deuteronomy offers a bird's-eye view of the entire history of Israel, shortly to be recounted in detail in Joshua through 2 Kings". R. Polzin, Deuteronomy, in: The literary guide to the Bible, R. Alter, F. Kermode (eds.), Cambridge (MA) 1990, Harvard University Press, p. 92; M. Rose, Deutéronome, in: Introduction à l'Ancien Testament, T. Römer, J. D. Macchi, Ch. Nihan (eds.), Genève 2009, Labor et Fides, p. 294.

3 A. D. H. Mayes, Deuteronomy, (The New Century Bible Commentary), Grand Rapids (MI) 1991, Wm.B. Eerdmans Publishing Company, p. 28.

4 B. S. Childs, Introduction, p. 224.

5 M.Z. Brettler, How to read the Bible, Philadelphia 2006, The Jewish Publication Society, p. 92-93.

6 Scripture quotations from the New Revised Standard Version of the Bible are copyright (C) 1999 by Oxford University Press, Inc. 
The first significant words of the fragment quoted above - "These are the words" (Hebr. 'elle(h) haddebārîm) - constitute the Hebrew title of the Book of Deuteronomy (Hebr. De $\underline{b} \bar{a} r \hat{\imath} m$ ). The English title of this book derives from the Latinized form of the Greek translation known as the Septuagint (LXX), which translated the Hebrew wording mišne $(h)$ hattôrāa(h) (Deut 17:18), that is "a copy of this law", as deuteronomion - "this repeated law" or "this second law"7. Both the word Debārîm ("words" or "speeches"), contained within the Hebrew name of Deuteronomy, and the Greek title of this book - Deuteronomion ("this repeated law") - directly indicate the aim of the last book of the Pentateuch. Deuteronomy was edited as the long speech of Moses, which was delivered to the people of Israel in the plains of Moab to the eastern side of the Jordan (Deut 1:1). The Book of Deuteronomy consists of three such extended speeches of Moses. The first one, which is the main subject of this analysis, is a general instruction containing some elementary requirements for Israel with whom God made a covenant ${ }^{8}$. Israelites listened to the words of their leader, which just repeated and explained the law which he was given by God at Mount Horeb (this is the name given in Deuteronomy to the mountain known as Sinai). Therefore, Moses can be named as the first commentator of the law conveyed in the Book of Deuteronomy 9 . Since Moses knew he was not allowed to enter into the Promised Land (see Num 20:12; Deut 3:25-27), he gave this farewell address to Israel before his death. As the teacher and instructor of Israel, Moses exhorted his compatriots to put their lives totally into God's hands.

The Jewish tradition emphasizes that the words of the people passing away can become, for those who are listening to them, durable words. This shows the meaning of the Hebrew word $d \bar{a} \underline{b} \bar{a} r$ that can be translated as "a word" as well as "a thing". The Rabbis teach that the farewell speech of Moses contains the most important message of the whole Pentateuch which, to certain extent, the following fragment of Deuteronomy expresses: "I call heaven and earth to witness against you today that I have set before you life and death, blessings and curses. Choose life so that you and your descendants may live, loving

7 A. D. H. Mayes, Deuteronomy, p. 27.

8 The covenant made by God with Israelites "is a theological articulation of the God-Israel relationship". A. F. Campbell, M. A. O'Brien, Unfolding the Deuteronomistic History: origins, upgrades, present text, Minneapolis (MN) 2000, Fortress Press, p. 39.

9 J. L. Ska, Introduction to Reading the Pentateuch, Winona Lake (IN) 2006, Eisenbrauns, p. 39. 
the Lord your God, obeying him, and holding fast to him; for that means life to you and length of days, so that you may live in the land that the Lord swore to give to your ancestors, to Abraham, to Isaac, and to Jacob" (Deut 30:19-20). As the quoted text shows, the human being's life was equated with loving God, which is only possible when a person belongs, first of all, to God, who desires to give a happy life now and for eternity to every human being. Therefore, in the Book of Deuteronomy Moses is exhorted to remove any obstacle standing between God and the person. The only strategy, according to Moses' teaching, to be a truly free and happy person is to try persistently to cling (Hebr. $d \bar{a} \underline{b} a q$ - literal "to stick to somebody or something", "to cling to somebody") $)^{10}$ to God (cf. Deut 30:20) ${ }^{11}$. Given the importance of the GodIsrael relationship in Deuteronomy, this throws a light on the point made earlier with reference to the understanding of the Old Testament law. Both the understanding of law in the Book of Deuteronomy, and the whole biblical portrayal of Israel's history with God, indicates that the relationship between them existed long before the laws were stipulated ${ }^{12}$. So it is clear that the relationship between God and the person is not conditional on obedience to the letter of the law but the obedience to the law is the consequence of such a relationship ${ }^{13}$. In this way Deuteronomy protects every believer against all form of legalism ${ }^{14}$. This book teaches that the obedience to the

${ }^{10}$ The Brown - Driver - Briggs Hebrew and English lexicon: with an appendix containing the biblical Aramaic, F. Brown, S. Driver, C. Briggs (eds.), Peabody (MA) (twelfth printing) 2008, Hendrickson Publishers, Inc., p. 179-180.

${ }^{11}$ Chamisza Chumsze Tora - Chumasz Pardes Lauder. Przekład Pięcioksięu z języka hebrajskiego z uwzględnieniem Tory Ustnej opatrzony wyborem komentarzy Rabinów oraz hebrajski tekst komentarza Rasziego i Haftary z błogosławieństwami. Księga Piąta Dewarim (Księga Powtórzonego Prawa), oprac. pod kierownictwem S. Pecarica, tłum. S. Pecaric, Kraków 2006, The Ronald S. Lauder Foundation, Edycja Pardes Lauder, p. XIV-XV.

12 A. F. Campbell, M. A. O’Brien, Unfolding the Deuteronomistic History, p. 40-41.

13 "In Deuteronomy (...) the view that the blessing of standing in covenant with Yahweh results from obedience to the commandments (see, for example, 7:12) is balanced and indeed out weighted by the view that Israel's status as the people of Yahweh is something real and actual before the covenant demands are made (see especially 27:9f.). And in the event of Israel's disobedience to these demands the operation of the covenant curse does not always mean that the covenant relationship is brought to an irrevocable end". A. D. H. Mayes, Deuteronomy, p. 78.

14 "According to Deuteronomy, the whole Mosaic law testifies to the living will of God whose eternal purpose for the life of his people provides the only grounds for life and salvation". B. S. Childs, Old Testament Theology in a Canonical Context, Philadelphia 1989, Fortress Press, p. 56. 
commandments is possible when someone tries forming a truly intimate relationship with God, who leads such a person always to love others through their concrete actions ${ }^{15}$.

Undoubtedly, a very important moment in Israel's history was the covenant made between God and his people at Mount Horeb. This helped to form a new and intimate relationship between them. There, God revealed himself to the Israelites and gave them the Ten Commandments, thus marking out that this event in the history of human civilization is of the immense importance. Moses remembered that very important event in the history of Israel in this manner: "Then the Lord spoke to you out of fire. You heard the sound of words but saw no form; there was only a voice. He declared to you his covenant, which he charged you to observe, that is, the ten commandments; and he wrote them on two stone tablets" (Deut 4:12-13). In the Book of Deuteronomy, the covenant (Hebr. $b^{e}$ rit $t$ ), that God made with Israel, is one of the ways of expressing the actual relationship between both of them ${ }^{16}$. The revelation of the law at Horeb was "the fullest and most direct expression of the will of God in the Old Testament" "17: that Israel should be obeyed if it only would try to be with God. Without the inner conversion, the faith, that is above all forming the intimate relationship with God, can be easily identified as merely obedience to the commandments, which leads to externalism ${ }^{18}$.

\section{Israel's faithfulness to the only and one God really does matter to their mutual relationship}

"Then, just as the Lord our God had ordered us, we set out from Horeb and went through all that great and terrible wilderness that you saw, on the way to the hill country of the Amorites, until we reached Kadesh-barnea. I said to you, «You have reached the hill country of the Amorites, which the Lord our God is giving us. See, the Lord your God has given the land to you; go up, take possession, as the Lord, the God of your ancestors, has promised you; do

15 "God has loved us first. The love of the One God is recalled in the first of the "ten words". The commandments then make explicit the response of love that man is called to give to his God". Catechism of the Catholic Church 2083.

${ }^{16}$ A. D. H. Mayes, Deuteronomy, p. 152.

${ }^{17}$ B. S. Childs, Old Testament Theology, p. 53.

18 J. Jensen, God's word to Israel, Collegeville (MN) 1988, The Liturgical Press, p. 108. 
not fear or be dismayed» (...) But you were unwilling to go up. You rebelled against the command of the Lord your God (...) But in spite of this, you have no trust in the Lord your God (...)" (Deut 1:19.26.32).

As mentioned earlier, the Book of Deuteronomy is concerned, first of all, with the question of the God-Israel relationship. Therefore, it is necessary to notice that Israel's faith is the most important challenge in her relationship with God. The emphasis on that matter has its background in the dramatic events which occurred during Israel's wandering through the desert. In the fragment quoted above we find the name of the oasis Kadesh-barnea where Israelites made a camp after they had left Mount Horeb. From that place some men of Israel were sent to explore the land of Canaan: the land that God promised to give to his people. Unfortunately, after they returned from exploring that country a true report was not given to the rest of Israelites and these then rose in rebellion against God. As a consequence of Israel's lack of faith in God, entering the Promised Land was delayed (see Num 13-14). In the Book of Deuteronomy this dramatic event summoned up the memory from the past of Israel to emphasize the problem of the unfaithfulness of Israelites in their relationship with God. It is the most suitable moment to notice that, despite Israel's reaction as a faithless disobedience to the will of God, the promise of the land was kept, even if only the next generation of Israelites saw its fulfilment ${ }^{19}$.

After the sad accident at Kadesh-barnea, the Book of Deuteronomy shows how the fate of Israel was changing when the people tried their life placing in God's hands (Deut 2:1-3:11). When Israelites started to rely on God alone, obeying his will, then, they were successful irrespective of forthcoming obstacles. For example, there was no sign of hostility when Israel was passing by the countries of her enemies: Edomites, the descendants of Esau (Gen 36; Deut 23:8), Moabites and Ammonites, the descendants of Lot (Gen 19:30-38). Moses named those people "the brothers"(Deut 2:8) and the soils belonged to those nations were shown as a God's gift (Deut 2:5.9.19). Even if Israelites were forced to struggle with the other tribes to enter into the Promised Land they recognized who exactly really these battles were won by. The biblical narrative recounting Israel's victories over the pagans wants, first of all, to show how it is important to destroy everything that disturbs one in being faithful to God alone. All

\footnotetext{
19 A. D. H. Mayes, Deuteronomy, p. 127.
} 
Israel's victories over her enemies - even with God's help - do not signify that God fought against any one person or any particular nation. Rather this fact shows God's engagement to defeat any human being, society or any evil that really disturbs one's vital relationship with God $^{20}$. At this point it is important to recall that the Book of Deuteronomy contains a literary strand that derives from the so-called deuteronomistic redaction which reinterpreted Israel's crisis of 587 B.C.E. (Nebuchadnezzar's destruction of Jerusalem) and the ensuing period of the Babylonian exile ${ }^{21}$. The spatial perspective, both of Moses' audience and of the biblical narrator's audience, which was in exile, are similar, that is, outside the Promised Land ${ }^{22}$. In the light of these really dramatic sufferings of Israel, the people forming the deuteronomistic movement, those responsible for the final process of editing Deuteronomy (the so-called 'Deuteronomist'), emphasized everything that expressed the importance of the uniqueness of the God-Israel relationship. This deuteronomistic contribution to the theology of Deuteronomy showed a clear understanding of the problem of Israel's unfaithfulness to God and the dramatic consequence of $i^{23}$. As with the biblical Israelites, the nearness of God to his people protected them from any evil of the polytheistic world, so too the intimacy of a relationship with God protects every human being against any form of internal and external evil. What is more, according to the pagan's views of the times, there was the immense gap between a deity and its worshiper. Therefore, Deuteronomy strongly emphasized the extraordinary closeness between God and Israel: "For what other great nation has a god so near to it as the Lord our God is whenever we call to him?” (Deut 4:7).

${ }^{20}$ J. L. Ska, Les énigmes du passé. Histoire d'Israël et récit biblique, (Le livre et le rouleau), traduit de l'italien par E. Di Pede, Bruxelles 2001, Éditions Lessius, p. 83-86.

${ }^{21}$ About the Deuteronomistic editing of Deuteronomy see A. D. H. Mayes, Deuteronomy, p. 41-47. "The book of Deuteronomy stands as the primal example of the dynamism of the Torah tradition whereby old memories are endlessly re-presented and reinterpreted, rearticulated, and reimagined in ways that keep the main claims of faith pertinent and authoritative in new circumstances". W. Brueggemann, An introduction to the Old Testament: the canon and Christian imagination, Louisville (KY) 2003, Westminster John Knox Press, p. 93.

${ }^{22}$ R. Polzin, Deuteronomy, p. 92.

${ }^{23} \mathrm{~J}$. Jensen characterizing the spirit of Deuteronomy in that context wrote: "As God's covenant people, Israel's only raison d'être, and therefore its only ground of hope, was faithfulness to the God who called her into being-and this was precisely what was lacking”. J. Jensen, God's word to Israel, p. 104-105. 


\section{The fullness of life in the Promised Land as a consequence of having an intimate relationship with God}

"So now, Israel, give heed to the statutes and ordinances that I am teaching you to observe, so that you may live to enter and occupy the land that the Lord, the God of your ancestors, is giving you. You must neither add anything to what I command you nor take away anything from it, but keep the commandments of the Lord your God with which I am charging you" (Deut 4:1-2).

The quoted fragment above clearly shows the direct connection between the possession of the Promised Land, that is the gift of God, and Israel's obedience to the commandments. The land, that is a central point to Deuteronomy's theology, is the place where the divine laws must be obeyed, because that is the only way for Israel to enter there. "For Deuteronomy life itself means life in the land in covenant with Yahweh"24 that is "a theological articulation of the God-Israel relationship"25. According to the Jewish tradition, there is the only one way to enter the Promised Land and live there: obedience to the commandments given by $\mathrm{God}^{26}$. In this context, Moses reminded Israel of another sad event that happened at Mount Peor in Moab where Israelites worshipped at that cultic place the local manifestation of the deity named Baal: "You have seen for yourselves what the Lord did with regard to the Baal of Peor - how the Lord your God destroyed from among you everyone who followed the Baal of Peor" (Deut 4:3). In this way the Book of Deuteronomy emphasizes that there is no middle ground "between the alternatives of faithful adherence to Yahweh and rejection of Him in favor of other gods" 27 . Therefore in the following verses Moses juxtaposed the Israelites' unfaithfulness to God at Peor with the faithful adherence to him, to show that those who held fast to God can live in the Promised Land: "While those of you who held fast to the Lord your God are all alive today. See, just as the Lord my God has charged me, I now teach you statutes and ordinances for you to observe in the land that you are about to enter and occupy" (Deut $4: 4-5)$. So those Israelites who formed a personal genuine relationship with God were always led to the obedience to divine will, expressed in the law

\footnotetext{
${ }^{24}$ A. D. H. Mayes, Deuteronomy, p. 81.

${ }^{25}$ A. F. Campbell, M. A. O'Brien, Unfolding the Deuteronomistic History, p. 39.

${ }^{26}$ Chamisza Chumsze Tora-Chumasz Pardes Lauder, p. 55.

27 J. Jensen, God's word to Israel, p. 107-108.
} 
which serves them as the essential rule of life in the Promised Land. It is worth noting, too, that in the last cited text the Hebrew word $d \bar{a} \underline{b} a q$ appeared again; translated here as "hold fast to", that literally means "to stick to" or "to cling to somebody". So it can be understood as synonymous with love or devotion. The Book of Deuteronomy uses this Hebrew term $(d \bar{a} \underline{b} a q)$ when talking about the relationship of God and Israel (cf. Deut 10:20; 11:22; 13:4; $30: 20)^{28}$. This is the key that describes God's unconditional mercy and desire for the closeness of every human being. Thus, the opportunity to obey the commandments, given as a rule of life, is offered to every person, because God and his word are always near (cf. Deut 30:14).

\section{The real obstacle that prevents Israel from forming a relationship with God}

"So that you do not act corruptly by making an idol for yourselves, in a form of any figure - the likeness of male or female, the likeness of any animal that is on the earth, the likeness of any winged bird that flies in the air, the likeness of anything that creeps on the ground, the likeness of any fish that is in the water under the earth. And when you look up to the heavens and see the sun, the moon, and the stars, all the host of heaven, do not be led astray and bow down to them and serve them, things that the Lord your God has allotted to all the peoples everywhere under heaven" (Deut 4:16-19).

The Book of Deuteronomy insists on the Israelites' fidelity to the one God because that is the only reason for Israel's existence as God's covenant people. God's love for Israel forms the basis of the unique relationship between them and demands from God's chosen people a continuing faithful response. The Israelites' response should be given to God by the adherence to and the worship of him alone because that constitutes the most essential element of that relationship ${ }^{29}$. To keep that relationship alive with God, Israel should avoid anything that may endanger the sole lordship of Yahweh for her. For this reason, the first commandment was given immense importance through extended commentary in the Book of Deuteronomy (see Deut 4:15-24; 5:6-10; 6:4-9). The above quoted text (Deut 4:16-19) lists the possible likenesses that

\footnotetext{
${ }^{28}$ A. D. H. Mayes, Deuteronomy, p. 211.

29 J. Jensen, God's word to Israel, p. 104-105.
} 
were used at that time for the idolatrous cults which were opening the way to Israelites for apostasy and eventually was taking them away from a full life which a vital relationship with God truly gives. In the aforementioned text, the catalogue of the objects of worship was presented but they were showed in reverse order than the same ones listed in the Book of Genesis as the elements of God's creation (Gen 1$)^{30}$. The prohibition of making any material images of God stems from the fact that Israelites did not see the shape of the figure that spoke to them during the theophany at the Mount of Horeb (Sinai). That is why Moses told them: "Since you saw no form when the Lord spoke to you at Horeb out of the fire" (Deut 4:15). To show the extraordinary position of Israel which had the privilege of being close to God the contrast between Israelites and pagans was shown, when Moses reminded Israelites they are God's possession: "But the Lord has taken you and brought you out of the iron-smelter, out of Egypt, to become a people of his very own possession, as you are now" (Deut 4:20). According to the Book of Deuteronomy, when the Israelites who were living in a false reality and an unreal idolatrous world, felt the dissonance with their call to form a unique relationship with the only true God, they turned back to look for God: "From there you will seek the Lord your God, and you will find him if you search after him with all your heart and soul. In your distress, when all these things have happened to you in time to come, you will return to the Lord your God and heed him. Because the Lord your God is a merciful God, he will neither abandon you nor destroy you; he will not forget the covenant with your ancestors that he swore to them" (Deut 4:29-31). In that context the Jewish tradition explains that the desire to find God means that such a person already forms a kind of relationship with God. The fragment above encourages every person that seeks God's nearness to do that with all one's heart, meaning the complete commitment of oneself, because it is necessary for the purpose of forming the truly relationship with God. Since the love for God is rooted in the every person's heart, therefore it is necessary to love from the heart. In doing this, the commandment sounds like a promise: "You shall love the Lord your God with all your heart, and with all your soul, and with all your might" (Deut 6:5) ${ }^{31}$. To love God in such way that causes everybody to want to live a happy life to the full, loving one's fellow beings in the most

\footnotetext{
${ }^{30}$ A. D. H. Mayes, Deuteronomy, p. 153.

${ }^{31}$ Chamisza Chumsze Tora-Chumasz Pardes Lauder, p. 62.
} 
practical way it is necessary to eliminate every sign of a pagan worship. Therefore, Deuteronomy gives the exhortations and the laws that are directed towards encouraging Israel's greater faithfulness to God, because that is the most effective way of eradicating of any form of idolatry ${ }^{32}$.

From what was said above one can conclude that the real obstacle that prevents Israel from forming the relationships with God was every kind of the pagan idolatry. Paradoxically, the best way to prevent forming a relationship with any idol (that is always a toxic and unreal one) is both true desire of, as well as looking for, the real God. Loving God with the entire heart, that is the seat of the human intellect and will, and with the whole soul, as the source of desire, is the best possible defense against all kind of idols. These idols can be everything: a person as well as any other reality that is being put at the center of one's life instead of real God ${ }^{33}$. Since there is no the middle ground between good and evil, life and death, so the warning against any forms of idolatry that prevents a person from forming the relationship with God, that is the purpose of human existence, remains in force for everyone.

\section{Conclusion}

The closing excerpt of the first farewell speech of Moses repeats the exhortation to be obedient to God's law in order to enjoy a happy life in the Promised Land: "Keep his statutes and his commandments, which I am commanding you today for your own well-being and that of your descendants after you, so that you may long remain in the land that the Lord your God is giving you for all time" (Deut 4:40). This means that both the gift of the Promised Land and the law given to Israel were meant as a great help to the Israelites in their search for the life-giving closeness with God and that personal relationship with him. The relationship between God and Israel as the biblical portrayal of the bond between God and the person therefore is the central message of the Bible. In the light of the Holy Scriptures the purpose

${ }^{32}$ The insistence in the book of Deuteronomy on the destruction of pagans and their cultic places above all served as a warning against everything what could contaminate the worship serving Israelites to be with Yahweh alone. J. Jensen, God's word to Israel, p. 105-106.

${ }^{33}$ In that context B. S. Childs wrote: "The ability of Deuteronomy to summarize the Law in terms of loving God with heart, soul and mind is a major check against all forms of legalism". B. S. Childs, Old Testament Theology, p. 56. 
of human life is to be with God forever. That is, why the God who revealed himself to mankind desires to be known by everyone. God's desire was accomplished in the life and mission of his beloved Son, Jesus Christ, who by his passion, death and resurrection gave to every human being the possibility of eternal salvation (cf. Jn 12:32).

\section{Bibliography}

Brettler M. Z., How to read the Bible, Philadelphia 2006, The Jewish Publication Society.

The Brown - Driver - Briggs Hebrew and English lexicon: with an appendix containing the biblical Aramaic, F. Brown, S. Driver, C. Briggs (eds.), Peabody (MA) (twelfth printing) 2008, Hendrickson Publishers, Inc.

Brueggemann W., An introduction to the Old Testament: the canon and Christian imagination, Louisville (KY) 2003, Westminster John Knox Press.

Campbell A. F., O'Brien M. A., Unfolding the Deuteronomistic History: origins, upgrades, present text, Minneapolis (MN) 2000, Fortress Press.

Childs B. S., Old Testament Theology in a Canonical Context, Philadelphia 1989, Fortress Press.

Childs B. S., Introduction to the Old Testament as Scripture, Philadelphia 2011, Fortress Press.

Chamisza Chumsze Tora - Chumasz Pardes Lauder. Przekład Pięcioksięgu z języka hebrajskiego z uwzględnieniem Tory Ustnej opatrzony wyborem komentarzy Rabinów oraz hebrajski tekst komentarza Rasziego i Haftary z błogosławieństwami. Księga Piąta Dewarim (Księga Powtórzonego Prawa), oprac. pod kierownictwem S. Pecarica, tłum. S. Pecaric, Kraków 2006, The Ronald S. Lauder Foundation, Edycja Pardes Lauder.

Jensen J., God's Word to Israel, Collegeville (MN), The Liturgical Press.

Mayes A. D. H., Deuteronomy (The New Century Bible Commentary), Grand Rapids (MI) 1991, Wm.B. Eerdmans Publishing Company.

Polzin R., Deuteronomy, in: The literary guide to the Bible, R. Alter, F. Kermode (eds.), Cambridge (MA) 1990, Harvard University Press, p. 92-101.

Rose M., Deutéronome, in: Introduction à l'Ancien Testament, T. Römer, J. D. Macchi, Ch. Nihan (eds.), Genève 2009, Labor et Fides, p. 294-331.

Ska J. L., Introduction to reading the Pentateuch, Winona Lake (IN) 2006, Eisenbrauns.

Ska J. L., Les énigmes du passé. Histoire d'Israël et récit biblique, (Le livre et le rouleau), traduit de l'italien par E. Di Pede, Bruxelles 2001, Éditions Lessius. 